\title{
Marine PAK1-blockers for Therapy of COVID-19
}

\author{
Hiroshi Maruta* \\ PAK Research Center, Melbourne, Australia \\ Received Date: December 08, 2020; Published Date: January 21, 2021 \\ *Corresponding author: Hiroshi Maruta, PAK Research Center, Melbourne, Australia
}

Keywords: PAK1, Fucoidan, Heparin, Astaxanthin, Frondoside A, COVID-19eotide

\section{Introduction}

In order to prevent COVID-19 infection or treat its patients world-wide, we have to know precisely how this virus replicates, and causes fibrosis (inflammation of lungs) in the end. As we previously discussed the matter in detail [1], COVID-19 is an RNA virus which requires RNA dependent RNA polymerase (RdRP) in host cells for replication, and the major "pathogenic" kinase called PAK1 (RAC/CDC42-activated kinase 1) for causing the inflammation. Thus, in principle, RdRP inhibitors can block the replication of this virus. However, so far none of RdRP inhibitors available in the market showed remarkable effect to treat COVID-19 patients world-wide. Besides most of RdRP inhibitors are ATP antagonists, and cause side effects which are due to inhibition of many other ATP-dependent enzymes such as kinases, ATPases, ATP-dependent chaperons and so on. Alternatively, PAK1-blockers in general cause no (or little) side effect, and at least (i) block the fibrosis, the main cause of death, and (ii) stimulate our immune system to neutralize the virus. In addition, there is an increasing evidence(s) indicating that viral entry into host cells requires PAK1 as well. Thus, PAK1-blockers readily available in the market would be much better than RdRP and vaccine, development of the latter taking at least a year, and would be no longer useful when the viral genome is mutated to change its antigenicity. Thus, here a few marine compounds or organisms readily available in the market will be introduced.

\section{Fucoidan}

First of all, Fucoidan is a sulphated polysaccharide from eadible brown or red seaweeds (Figure 1). According to a recent report from a Chinese group, fucoidan binds tightly the spike protein of COVID-19, blocking its binding to the receptor called ACE-2 on the surface of host cells [2]. In addition, as a PAK1blocker (activating PTEN, a phosphatase, which down-regulates
PAK1), fucoidan would suppress fibrosis in lungs, as well as stimulate our immune system, producing antibody against COVID-19. Back in 1919, Flu virus pandemic called "Spanish Flu" caused 50 million death tolls (with worldwide death rate= $10 \%$ ). Interestingly, however, its death rate in Korea and Japan was only $2 \%$. The major factor for this extremely low death rate has been strongly suggested, if not proven as yet, to link closely to everyday consumption of seaweeds by the people in this far-east area. Just like Fucoidan, heparin is also a sulphated polysaccharide and has a similar anti-COVID-19 activity [3]. Heparin was discovered in 1916 and is produced by basophils and mast cells in mammals and used mainly as an anti-coagulant (blocking platelet aggregation). Heparin blocks the thrombin/EGF-induced mitogenic/oncogenic signal pathway including EGFR, PAK1 and ERKs via heparinbinding EGF like growth factor [4-6].

\section{Astaxanthin}

Astaxanthin (AX) is a carotenoid (Figure 2) which is produced by red salmon and some other marine animals as well as red seaweeds. According to a 2011 article from a Japanese team, AX extends the healthy lifespan of C. elegans by $16-30 \%$ [7], clearly indicating that $\mathrm{AX}$ is an elixir that promotes the longevity. Furthermore, AX and several other carotenoids activate p21 (CDKinhibitor) gene, which is suppressed by PAK1, indicating that AX is among PAK1-blockers [7]. Furthermore, according to a 2020 report from an Indian team, AX possesses both anti-inflammatory and immune promoting activities [8] (Figure 2), clearly backing up the notion that $\mathrm{AX}$ is a PAK1-blocker.

\section{Saponins}

In addition to these marine PAK1-blockers readily available in the market, there is another PAK1-blocker "Frondoside A" (FRA in short, see Figure 3) from a sea cucumber called Cucumaria 
frondosa. FRA was isolated around 2008 by Tom Adrian's team as a potent anti-cancer sulphated saponin (IC50 around 1 micro-M), but later we found that FRA directly inhibits PAK1 in vitro with IC50 below 1 micro-M, in a very selective manner $[9,10]$. Furthermore, a similar saponin but desulphate form of FRA was isolated by us from another sea cucumber called Holothuria atra living along the coastline of Okinawa Islands, and appears to inhibit PAK1 without sulphation [11]. Although these saponins per se are not avaialable in the market, these eadible sea cucumbers are available in the market as healthy diets. Both saponins are soluble in hot-water, and easily extractable from these sea cucumbers by boiling water. Thus, it would be worth mentioning here.

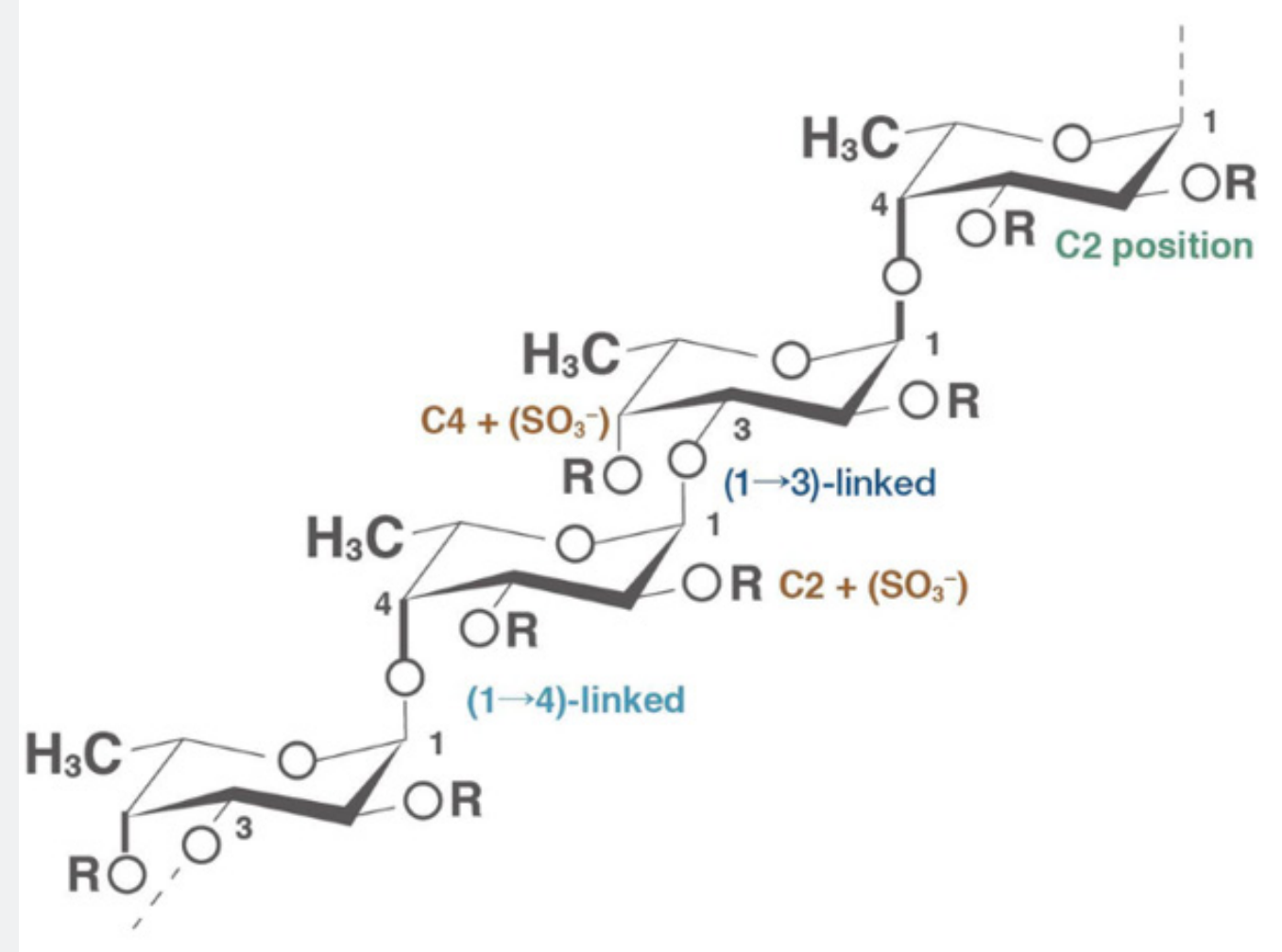

Figure 1: Fucoidan.

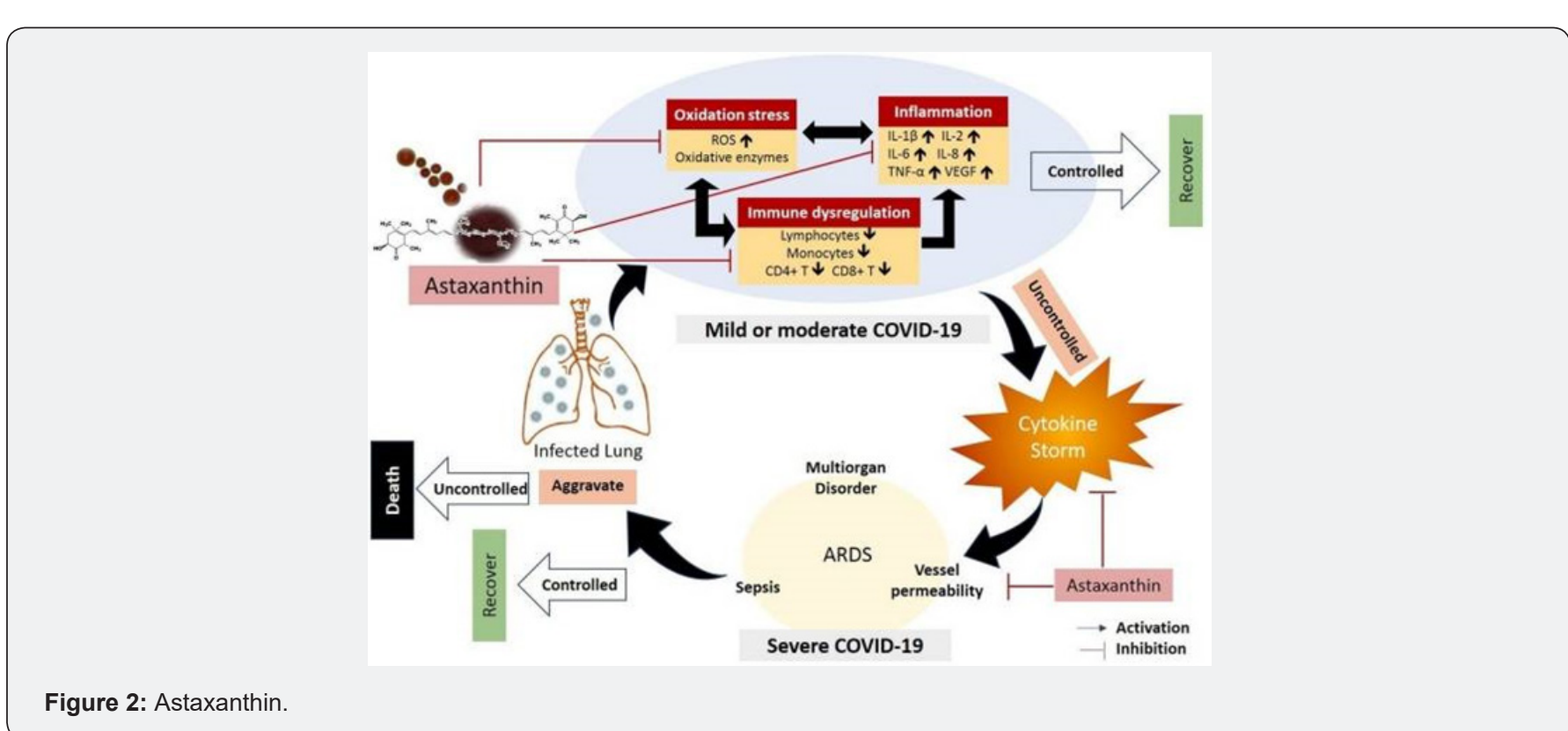




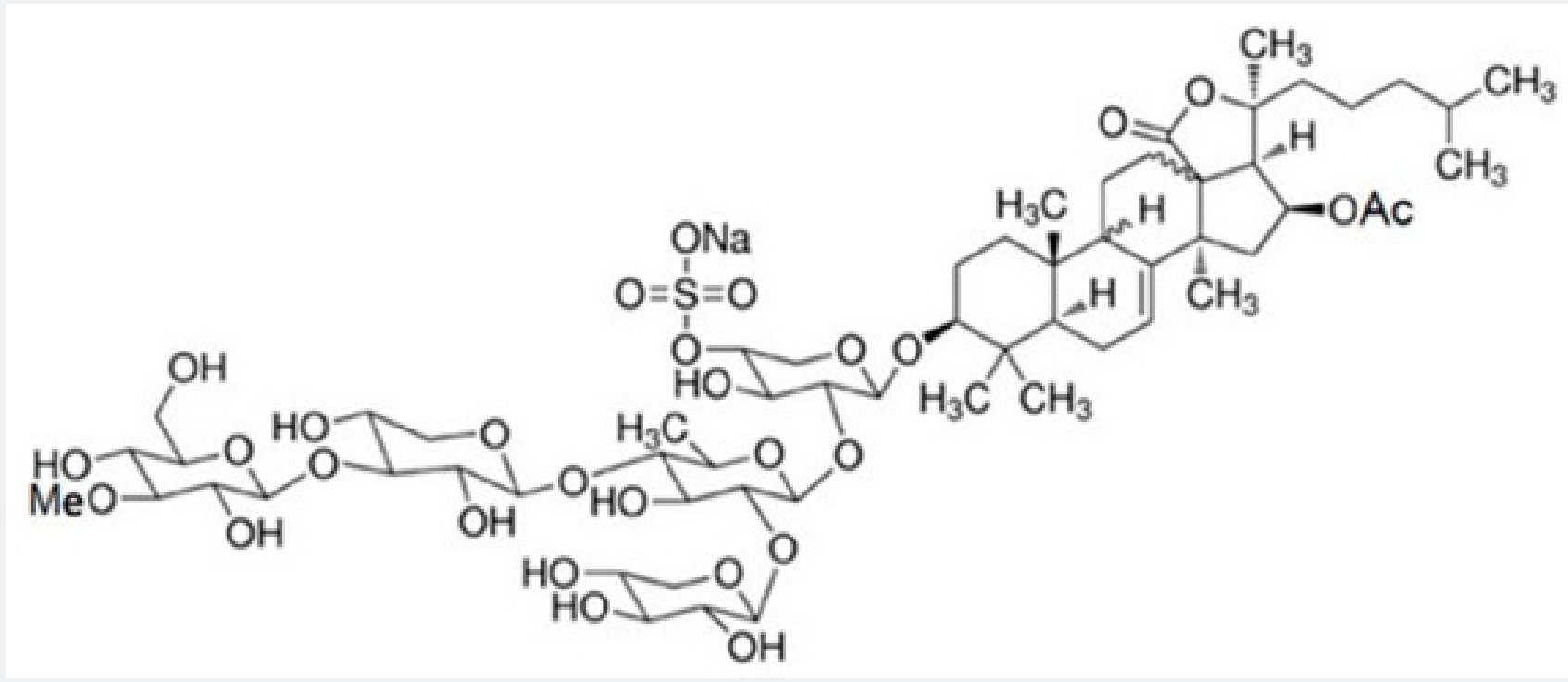

Figure 3: Frondoside A (FRA).

Lastly, Holotoxin, a third saponin isolated from Stichopus japonicus (Selenka), an eadible sea cucumber harvested along the coastline of Far-East Asia (Japan, Korea, China and Russia) was found by a Japanese scientist around 1969 as a potent anti-fungal saponin [12], and then later sold mainly among therapeutics of socalled "Athlete's Foot". Interestingly, both growth and movement of fungi in general depend on PAK1, and another "Athlete's Foot" therapeutic called Terbinafine (or Lamisil) has been proven by a Taiwanese group in Taipei to be a PAK1-blocker [13]. Thus, it is most likely that many of "Athelete's Foot" therapeutics, if not all, could be among PAK1-blockers useful for COVID-19 treatment.

\section{References}

1. Maruta H, He H (2020) PAK1-blockers: Potential Therapeutics against COVID-19. Med Drug Discov 6: 100039.

2. Jin W, Zhang W, Mitra D, Martin G, Zang F, et al. (2020) The structureactivity relationship of the interactions of SARS-CoV-2 spike glycoproteins with glucuronomannan and sulfated galactofucan from Saccharina japonica. Int J Biol Macromol 163: 1649-1658.

3. Hippensteel J, LaRiviere WB, Colbert JF, Eric P, Christope JL (2020) Heparin as a therapy for COVID-19: current evidence and future possibilities. Am J Physiol Lung Cell Mol Physiol; 319(2): L211-L217.

4. Hedin U, Daum G, Clowes AW (1998) Heparin inhibits thrombininduced mitogen-activated protein kinase signaling in arterial smooth muscle cells. J Vasc Surg 27(3): 512-520.

5. Teo M, Manser E, Lim L (1995) Identification and molecular cloning of a p21cdc42/rac1-activated serine/threonine kinase that is rapidly activated by thrombin in platelets. J Biol Chem 270(44): 26690-26697.
6. Kalmes A, Vesti BR, Daum G, Abraham JA, Clowes AW (2000) Heparin blockade of thrombin-induced smooth muscle cell migration involves inhibition of epidermal growth factor (EGF) receptor transactivation by heparin-binding EGF-like growth factor. Circ Res 87(2): 92-98.

7. Yazaki K, Yoshikoshi C, Oshiro S, Yanase S (2011) Supplemental cellular protection by a carotenoid extends lifespan via Ins/IGF-1 signaling in Caenorhabditis elegans. Oxid Med Cell Longev 2011: 596240.

8. Talukdar J, Bhadra B, Dattaroy T, et al (2020) Potential of natural astaxanthin in alleviating the risk of cytokine storm in COVID-19. Biomed Pharmacother 132: 110886.

9. Li X, Roginsky AB, Ding XZ, et al (2008) Review of the apoptosis pathways in pancreatic cancer and the anti-apoptotic effects of the novel sea cucumber compound, Frondoside A. Ann N Y Acad Sci 1138: 181-198.

10. Nguyen BCQ Yoshimura K, Kumazawa S, Tawata S, Maruta H (2017) Frondoside A from sea cucumber and nymphaeols from Okinawa propolis: Natural anti-cancer agents that selectively inhibit PAK1 in vitro. Drug Discov Ther 11(2): 110-114.

11. Shahinozzaman Md, Ishii T, Takano R, Halim Md, Hossain A, et al. (2018) Cytotoxic Desulfated Saponin from Holothuria atra Predicted to Have High Binding Affinity to the Oncogenic Kinase PAK1: A Combined In Vitro and In Silico Study. Sci Pharm 86(3): E32.

12. Shimada S (1969) Antifungal steroid glycoside from sea cucumber. Science 163(3874): 1462.

13. Wen-Sen Lee, Rong-Jane Chen, Ying-Jan Wang, Tseng H, Jeng HJ, et al. (2003) In vitro and in vivo studies of the anticancer action of terbinafine in human cancer cell lines: G0/G1 p53-associated cell cycle arrest. Int J Cancer 106(1): 125-137. 
This work is licensed under Creative Commons Attribution 4.0 License

DOI: 10.19080/NAPDD.2021.05.555667

\section{Your next submission with Juniper Publishers} will reach you the below assets

- Quality Editorial service

- Swift Peer Review

- Reprints availability

- E-prints Service

- Manuscript Podcast for convenient understanding

- Global attainment for your research

- Manuscript accessibility in different formats

( Pdf, E-pub, Full Text, Audio)

- Unceasing customer service

Track the below URL for one-step submission

https://juniperpublishers.com/online-submission.php 